\title{
Agronomic Management of Water Chestnut (Trapa natans L.): A Review
}

\author{
B. R. Jana* \\ ICAR-RCER, Research Centre for Makhana, Darbhanga-846005, Bihar, India \\ *Corresponding author
}

\begin{tabular}{l} 
K e y w o r d s \\
$\begin{array}{l}\text { Water chestnut, } \\
\text { horticulture, Bihar } \\
\text { large red, Green } \\
\text { spineless and } \\
\text { Balasore green }\end{array}$ \\
\hline Article Info \\
$\begin{array}{l}\text { Accepted: } \\
\text { 22 July 2020 } \\
\text { Available Online: } \\
\text { 10 August } 2020\end{array}$ \\
\hline
\end{tabular}

\section{A B S T R A C T}

Water chestnut is an important high value aquatic crop grown in India. Of late the importance of this crop has been increasing due to the presence of appreciable amount of nutritional contents therein like protein, carbohydrates, fiber and minerals. This paper explores the recent agronomic management techniques and post-harvest utilization of water chestnut crop. Being a short duration annual crop, it can be introduced in low-input cropping systems as a viable alternative crop for sustainable horticulture. Water chestnut production is mainly constrained by lack of knowledge on agronomic practices, deficiency of technical know-how about its processing and lack of mass awareness about its high nutritional values. These days, field cultivation of this crop is also proving to be profitable. Hence, attempts are being undertaken to integrate it with field crops. Improved genotypes namely Bihar Large Red, Green Spineless and Balasore Green have been found to perform the best under field cultivation. Planting distance of $1 \mathrm{~m} \times 2 \mathrm{~m}$ with application of NPK @ $60: 40: 30 \mathrm{~kg} / \mathrm{ha}$ in split applications have witnessed a yield of as much as $12.0 \mathrm{t} / \mathrm{ha}$. Being a high value cash crop, it can be sold as the fresh produce; better income however can be secured by selling value added products of water chestnut like dry nut and flour. Cultivated with right agronomic techniques and processed appropriately after harvest, water chestnut crop can significantly improve the livelihood of farmers living in water surplus regions of rural India.

\section{Introduction}

Water chestnut (Trapa natans L.) is one of the most important aquatic nuts grown in India. It is an important nut in terms of protein, carbohydrates, mineral and vitamin content along with important amino acids (Faruk et al., 2012). Nutritional and medicinal qualities of Trapa natans have been recognized in India, China, Thailand, Russia and many other countries (Hummel and Kiviat, 2004).
In India, Trapa natans, T. bispinosa,T. qudrispinosa and T. bicornis are very popular. Fresh nut is well known for its high water content (80.0\%) (Puste, 2004) protein (1.87\%) and TSS (7.0-8.0\%) (Singh et al., 2010). According to Adkar et al., (2014) and Alfasane et al., (2011) protein and carbohydrate content of fresh water chestnut are $4.40 \%$ and $22.3 \%$, respectively. Water chestnut is an excellent source of crude fiber $(2.13 \%$ in green variety and $2.27 \%$ in red 
variety). It is also a fair source of Vitamin B along with $\mathrm{Ca}, \mathrm{K}, \mathrm{Fe}$ and $\mathrm{Zn}$ (Singh et al., 2009 and Gopalan et al., 2004). Water chestnut is an eco-friendly crop and is utilized for prevention of cyano-bacterial bloom and addition of nutrients to the soil after decomposition of its residue. Trapa natans usually decreases dissolved inorganic nitrogen in water thereby potentially reducing eutrophication process in water bodies (Tsuchiya and Iwakuma, 1993). From aquatic environment, it absorbs heavy metals such as cadmium, nickel, and cobalt (USEPA, 1989) which are deposited mainly in hulls. According to Block and Morris (2002) one seed gives rise to 10-12 rosettes and each rosette produces as much as 20 fruits. It requires 4.0 months after transplanting for producing economic yield. It is very hardy crop requiring only 1-2 sprays of insecticides and fungicides for disease and pest free plant growth.

\section{Agronomic management techniques}

\section{Genotype}

Four types of water chestnut are mainly cultivated in India viz. spine and spineless with red and green color. The prominent genotypes of water chestnut are Spineless Red, Spineless Green (Jana et al., 2019). Red Spine, Bihar Large Red, Green Spine, Balia Red, Lucknow Green, Jaunpuri and Balasore Green (Jana, 2016a) which are common in all parts of India. However Balasore Green of Odisha gives relatively a better yield of 16.84 t/ha (Choudhary et al., 2003).

\section{Climate}

Water chestnut needs rather cool climate for its seed germination $\left(12-15{ }^{0} \mathrm{C}\right)$. For plant growth and development it needs little higher temperature $25-30^{\circ} \mathrm{C}$. However, fruit is generally harvested during cool winter
October-November (Block and Morris, 2002 and Kundu and Joshi, 2012).

\section{Soil and nutrient management}

It thrives in soft nutrient rich waters of lakes, ponds and streams with a neutral to slightly alkaline $\mathrm{pH}$. For commercial cultivation soil should be heavy, muddy and rich in organic matter. Organic manures in form of oil cakes, poultry manure and compost/FYM @ 8 t/ha are recommended for growth and development of water chestnut crop (Choudhary et al., 2003). Significant amount of phosphorus and potassium is needed for optimum growth of the crop. In West Bengal, application of $30-40 \mathrm{~kg}$ urea/ha during transplantation and another $20 \mathrm{~kg} / \mathrm{ha}$ is recommended after 25-30 days of transplanting (Jana, 2016a).Soils rich in $\mathrm{Zn}$ and $B$ result in increased number of fruits and fruit weight. For newly cultivated field, the fertilizer dose can be modified from NPK @ 60:20:20 kg/ha to NPK @ 60:40:30 kg/ha (Jana et al., 2019).

\section{Nursery raising and transplanting}

The seed rate for nursery preparation is 80$100 \mathrm{~kg}$ dry nut/ha. It is recommended that plants are first grown in a low nutrient plot/nursery and transplanted into main plot when stems are about 1.0-1.5 m tall. Care should be taken at the time of transplanting to keep the seedlings moist but not submerged. According to Jana et al., (2019) planting distance should be maintained at $1 \mathrm{~m} \times 2 \mathrm{~m}$ to give an optimum plant population of 4500 5000 plants/ha.

\section{Water level}

Throughout the growth period of the crop 1-2 $m$ water depth should be maintained for proper growth and development (Jana, 2016a) (Fig. 1). A greater depth of water is tolerated 
by the plants but they do not prosper if water shortage occurs at early period of growth. Prior to harvesting of the crop water depth may be reduced gradually.

\section{Reproductive stage}

Spineless Red cultivar flowers first at wetland ecosystem of North Bihar during $2^{\text {nd }}$ week of August. Blooming period continues to $1^{\text {st }}$ week of September. But Spineless Green cultivar has longer blooming period from August to October. Harvesting of the nuts is usually performed during October to December (Fig. 2). A well maintained local genotype gives the maximum yield of 2.5-3.5 t/ha (Jana, 2016). Bihar Large Red (Spine), the commercial variety of Mithila region, Darbhanga, India, gives a higher yield of 7.0 t/ha (Jana et al., 2019). The maximum yield of $12.0 \mathrm{t} / \mathrm{ha}$ can be achieved by cultivation of Green Spineless genotype (Jana et al., 2019). Regular eradication of aquatic weeds, especially Hydrilla and Sagittaria, common in makhana and water chestnut crop, is utmost important during the cropping season to avoid the crop-weed competition (Jana, 2016b)

Fig.1 Water chestnut plant

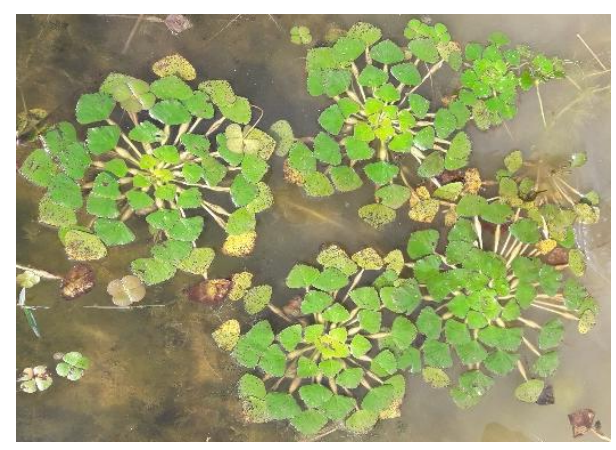

\section{Pest and disease management}

Beetle (Galerucella birmanica Jacoby) and aphid are the main pests under wetland ecosystem of Darbhanga, North Bihar. Two to three sprays of Carbaryl @ $0.05 \%$ at an interval of 7-10 days can control beetle (Galerucella birmanica Jacoby), aphid and mealy bug. Spray of Bavistin (0.1\%) is required to control fungal diseases (Yadav and Gargav, 1988).

\section{Value addition}

Traditionally water chestnut is consumed after boiling. This is high value nut from which sweets and precious chapatti may be made. Sun drying or artificial drying in oven is common in India. It's a medium to low calorie food with maximum nutrients which is gaining importance for making snacks for every class of people throughout the world. Nut is free from gluten and cholesterol and rich in $\mathrm{K}, \mathrm{Mg}$ and fiber, which renders it an ideal snack. Low cost mixed food can be made by mixing this nut flour with wheat and pulse flour to fortify its nutritional value (Sha et al., 2016; and Baba et al., 2016).

Fig.2 Harvesting of water chestnut

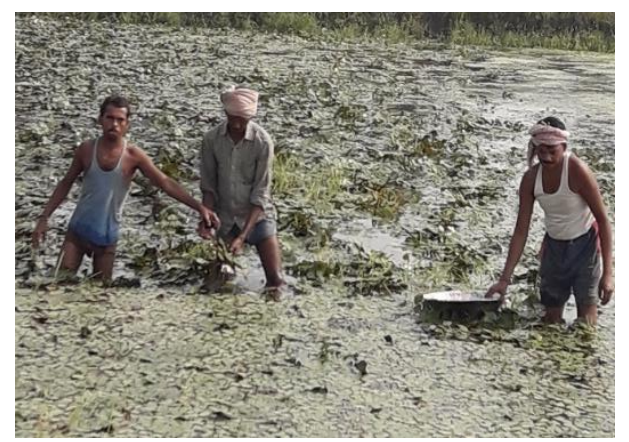


Fig.3 Green Spineless fresh nut

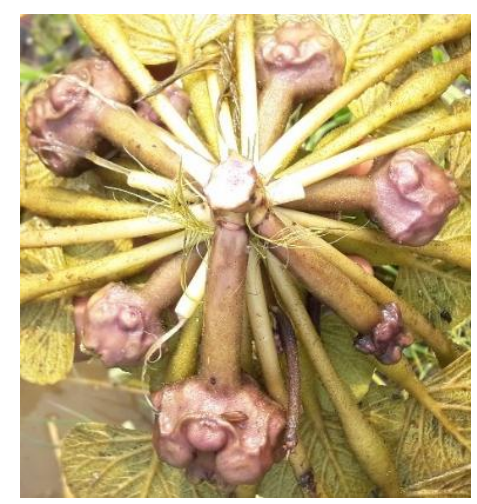

Water chestnut for enhancing rural livelihood sustainability

Water chestnut is a high value aquatic horticultural cash crop. High farmers' income can be secured by increasing production of water chestnut by cultivating high yielding genotypes, value addition and efficient marketing management. The net profit from water chestnut (fresh product) is about INR 1.87 lakh/ha/year (Jana, 2019) with production cost of about INR 0.6 lakh/ha/year. From the cultivation of superior genotype 'Green Spineless', a harvest of more than $2.0 \mathrm{t} /$ ha dry nut (Fig. 3 and 4 ) is possible which is worth INR 4.0 lakh/ha/year.

\section{Limitations and future prospects}

Necessary actions should be undertaken to keep ecosystem vibrant and get the maximum benefit from water chestnut crop. Crop residues are easily decomposed and add various plant nutrients to soil including organic matter for sustainable horticultural production system. Water chestnut cultivation is also a kind of bio-remediation by natural means. It is difficult to maintain its quality during processing which is essential for export, which merits particular attention. Water chestnut is a lucrative crop which requires mass awareness about nutritional qualities and consumption techniques for the
Fig.4 Green Spineless dry nut

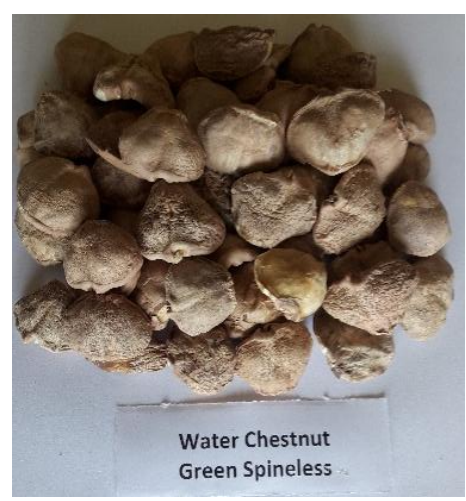

health conscious people. Water chestnut crop can significantly improve the livelihood of farmers living in water surplus regions of rural India if cultivated with right agronomic techniques and processed appropriately after harvest.

\section{Conflicts of interests}

There is no conflict of interests.

\section{References}

Adkar, P., A. Dongare, S. Ambavade and V.H. Bhaskar. 2014. Trapabis pinosa Roxb.: A review on nutritional and pharmacological aspects. Retrieved November 17, 2017, from

https://www.hindawi.com/journals/aps/20 14/959830/.

Alfasane, Md., M. Almujaddade, M. Khonder and M. Rahman. 2011. Biochemical composition of the fruits of water chestnut (Trapabis pinosa Roxb.). Dhaka Univ. J. Biol. Sci. 20(1), 95- 98, https://www.banglajol.info/index.php/DU JBS/article/view/8879/6590.

Baba, W.N., S. Din, H.A. Punoo, T.A. Wani, M. Ahmad and F.A. Masoodi. 2016. Comparison of cheese and paneer whey for production of a functional pineapple beverage: nutraceutical properties and shelf life. J. Food. Sci. Technol. 53, 2558-2568.

Block, A.F. and Morris T.A. 2002. Arboretum of 
the University of Pennsylvania. European water-chestnut Trapa natans L. Water chestnut family (Trapaceae). April, http://www.paflora.org/pdf/INV-

Fact\%20Sheets/Trapa\%20natans.pdf Updated 5/12.

Choudhary, S.R., N. Sahoo and N. Verma. 2003. Growth behavior and yield of five water chestnut varieties under waterlogged condition. Indian J. Plant Physiol. 8(4), 369-371.

Faruk, M.O., M.Z. Amin, N.K. Sana, R.K. Saha and R.K. Biswas. 2012. Biochemical analysis of two varieties of water chestnuts (Trapa spp). Pakistan Journal of Biological Sciences.15 (21), 1019-1026.

Gopalan, C., R. Sastri and S.C. Balasubramanian. 2004. Nutritive value of Indian foods, National Institute of Nutrition, ICMR, Hyderabad.

Hummel, M. and E. Kiviat. 2004. Review of world literature on water chestnut with implications for management in North America. J Aquat Plant Manage. 42, 17 27.

Jana, B.R. 2016b. The impact of water depth on growth of gorgon nut (Euryale feroxSalisb.) and associated weeds under field cultivation. Journal of Crop and Weed. 13(1), 77-82.

Jana, B.R. 2019. Exploring aquatic horticultural crops for higher income of farmers living in water surplus ecology. Model training1 , Recent advances in horticulture and post-harvest technologies for livelihood securities. SEET, ICAR-RCER, Patna, India, (19-26 December), p. 61-70.

Jana, B.R., B.P. Bhatt, I.S. Singh and Md. Idris. 2019. A study on commercial cultivation and storage of water chestnut (Trapa natans L.) under wetland ecosystem of
North Bihar, India. Journal of Applied and Natural Science. 11(2), 528-533.

Jana, H. 2016a. Water Caltrop: A potential crop of water bodies. Rastriya Krishi. 11(2), 7-11.

Kundu, M. and R. Joshi. 2012. Production technology of water chestnut (Trapa natans). Krisi sewa; p.1-2.

Puste, A. M. 2004. Agronomic management of wetland crops. Kalyani Publishers, India.

Sha, M., W.N. Baba, F.A. Masoodi and R. Bazaz. 2016. Wheat-water chestnut flour blends: effect of baking on antioxidant properties of cookies. J. Food. Sci. Technol., DOI 10.1007/s13197-016-2423-5 2016.

Singh, G.D., A.S. Bawa Singh and D.C. Saxena. 2009. Physicochemical, pasting, thermal and morphological characteristics of Indian water chestnut (Trapa natans) starch. Starch Stärke. 61, 35-42.

Singh, G.D., S. Singh, N. Jindal and Saxena, D.C. 2010. Physico-chemical characteristics and sensory quality of singhara (Trapa natans L.): An Indian water chestnut under commercial and industrial storage conditions. Afr. J. Food Sci. 4(11), p. 693 -702 .

Tsuchiya T. and T. Iwakuma 1993. Growth and leaf life-span of a floating-leaved plant, Trapa natans L., as influenced by nitrogen flux. Aquatic Botany. 46(3-4), 317-324.

USEPA. 1989. (U.S. Environmental Protection Agency). Superfund record of decision, Marathon Battery, NY, third remedial action - final. New York State Department of Environmental Conservation, Albany, NY.

Yadav, H.S. and V.P. Gargav. 1988. Chemical control of singhara beetle, Galerucella Birmanica Jacoby. Indian Journal of Plant Protection. 16, 159-162.

\section{How to cite this article:}

Jana, B.R. 2020. Agronomic Management of Water Chestnut (Trapa natans L.): A Review. Int.J.Curr.Microbiol.App.Sci. 9(08): 2773-2777. doi: https://doi.org/10.20546/ijcmas.2020.908.312 